\title{
BIOCHEMICAL AND DNA DAMAGE RESPONSES OF HYDROPONICALLY GROWN ELANDS SOURFIG (CARPOBROTUS ACINACIFORMIS L.) LEAVES TO CADMIUM STRESS CONDITIONS
}

\author{
KARAKAS, S. ${ }^{*}{ }^{*}$ DIKILITAS, M. ${ }^{2}-$ AKKURAK, H. $^{2}$ \\ ${ }^{1}$ Harran University, Faculty of Agriculture, Department of Soil Science and Plant Nutrition, \\ 63300 Sanliurfa, Turkey \\ ${ }^{2}$ Harran University, Faculty of Agriculture, Department of Plant Protection, 63300 Sanluurfa, \\ Turkey \\ *Corresponding author \\ skarakas@harran.edu.tr
}

(Received $14^{\text {th }}$ Dec 2020; accepted $14^{\text {th }}$ May 2021)

\begin{abstract}
Biochemical responses, DNA damages, and cadmium (Cd) accumulation capacity of Elands sourfig (Carpobrotus acinaciformis L.), a halophyte plant, were investigated under a variety of $\mathrm{CdNO}_{3}$ concentrations in hydroponic conditions for 30 days. Total chlorophyll/carotenoid and proline contents of the plants under differing $\mathrm{Cd}$ concentrations $(0-, 2.5-, 5-, 10-, 20-, 40-, 60-, 80$ and $100 \mathrm{ppm})$ gradually increased up to 20 and $40 \mathrm{ppm}$, respectively, which was followed by a decrease, $P \leq 0.05$. Accumulation of malondialdehyde (MDA, 3.22 to $22.87 \mathrm{nmol} \mathrm{g}^{-1}$ fresh weight, Fwt) and $\mathrm{H}_{2} \mathrm{O}_{2}\left(2.93-24.14 \mu \mathrm{mol} \mathrm{g}^{-1} \mathrm{Fwt}\right)$ contents showed an increasing trend along with higher Cd concentrations, $P \leq 0.05$. On the other hand, antioxidant enzymes such as peroxidase (POX) and catalase (CAT) exhibited increasing trends only up to $40 \mathrm{ppm}$ of $\mathrm{Cd}$ concentrations and the following drastic decline was evident, $P \leq 0.05$. The content of $\mathrm{Cd}$ levels in those leaves increased from 0.01 to $65.77 \mathrm{mg} \mathrm{kg}^{-1}$ with respect to $\mathrm{Cd}$ concentrations. DNA in leaves was not fragmented up to $5 \mathrm{ppm}$ Cd level. When DNA damage was assayed in a single cell via comet assay, 80- and $100 \mathrm{ppm}$ of Cd toxicity resulted in DNA breaks. Measuring DNA damage via comet assay could be a very useful approach to find out what level of $\mathrm{Cd}$ toxicity could be tolerated if a particular halophyte plant is used to remediate the Cd-contaminated media.
\end{abstract}

Keywords: heavy metals, cadmium toxicity, DNA fragmentation, halophytes, comet assay

\section{Introduction}

Heavy metals are one of the most significant environmental pollutants in nature. Their toxicity has now become a global issue since ecology, nutritional and humans' health are very much affected. Almost all heavy metals are non-essential and toxic to human and to the environment. Among heavy metals, cadmium has received much attention in soil science and plant nutritional studies due to its potential toxicity and its mobility in the soil-plant system (Tran and Popova, 2013; Shanmugaraj et al., 2019). Cadmium can be taken up by plant roots and enter the food chain resulting in a serious health issue for human beings. Even very low concentrations of $\mathrm{Cd}$ can cause significant toxicity and hamper the growth and development of plants (Al-Qurainy et al., 2017).

Cadmium has a long biological half-life originating mainly from industrial effluents, power stations, metal working industries, heating systems, batteries, urban traffic, etc. as well as application of fertilizers containing phosphates (Gill et al., 2013). Although it is non-essential, it is taken up very quickly by the plants and negatively affects the plant metabolism such as growth and development. $\mathrm{Cd}$ has a large solubility in water and has 
been ranked number seven among the top 20 toxins, therefore, $\mathrm{Cd}$ has been widely studied for its impacts on plant at various levels including metabolism (Bagheri et al., 2014).

In plants, the symptoms of Cd toxicity can be observed between slight injury and lethality. The main known mechanisms of Cd toxicity include its affinity for sulfhydryl groups in proteins and its ability to replace some essential metals in active sites of enzymes, thus causing inhibition of enzyme activities and protein denaturation (Garg and Bhandari, 2013; Tamás et al., 2014). It also alters the enzyme pathway and indirectly induces oxidative stress by generating reactive oxygen species (ROS) (Romero-Puertas et al., 2004; Xie et al., 2019). The ROS react with lipids, proteins, pigments and nucleic acids and cause oxidative damage including lipid peroxidation leading to membrane and DNA damages (Chien et al., 2001; Dutta et al., 2018).

Once absorbed by plants, Cd causes several metabolic and molecular changes in cells that leads to reduction in plant growth and increased leaf chlorosis and senescence (Dalcorso et al., 2008). Plants employ different defense mechanisms to prevent these biochemical and molecular damages including plant chelates and antioxidative defense, and low molecular weight substances such as thiols and metal-binding polypeptides. The plants have various antioxidant molecules such as ascorbate, glutathione, $\alpha$-tocopherol and enzymes such as superoxide dismutase (SOD), peroxidase (POD) and catalase (CAT), which protect the host from oxidative damage (Ahmad et al., 2017). Although many studies have shown that the effects of Cd on plants via decrease in photosynthesis and growth (Andresen and Küpper, 2013; Dias et al., 2013), disturbed nutrient uptake (López-Millán et al., 2009; Solti et al., 2011), and increases ROS accumulation (Jaskulak et al., 2018) have been evident. However, the mechanisms involved in toxicity are still need to be elucidated.

Cadmium inhibits the growth of lateral root formation in plants while the main root becomes brown, rigid, and twisted (Yadav, 2010; Xie et al., 2019). It has been shown that $\mathrm{Cd}$ interacts with various nutrient elements in terms of availability and transport from the soil (Nazar et al., 2012). For example, the mutagenic and cytotoxic nature of $\mathrm{Cd}$ causes DNA damage by producing ROS (Fodor, 2002; Dutta et al., 2018). Moreover, Cd binds to DNA bases and inhibits DNA mismatch repair (Al-Qurainy et al., 2017). Genotoxic disturbances could vary among plant species. For example, the genotoxic effect was varied among the plant organs of lettuce and tobacco as more effects were observed in the root while no changes were noticed in the leaf (Gichner et al., 2004; Monteiro et al., 2007). Similarly, the genotoxic effects of Cd in different concentrations were reported on Nicotiana tabacum, the effect was more pronounced in roots (Gichner et al., 2004). The oxidative DNA damage, chromosomal aberrations, DNA strand breaks, and the induction of micronuclei have all been observed in vivo and in vitro under $\mathrm{Cd}$ stress (Beyersmann and Hartwig, 2008). Different molecular markers such as microsatellite (simple sequence repeat, SSR) (Monteiro et al., 2007), random amplified polymorphic DNA (RAPD) (AlQurainy et al., 2010), and inter-simple sequence repeat (ISSR) (Al-Qurainy, 2010) have all been used to assess the genotoxicity of heavy metals in plants. In this study, genotoxicity was measured via DNA fragmentation along with the single cell gel electrophoresis (SCGE) methods to find out what level of $\mathrm{Cd}$ actually disrupts and permanently damages DNA of the host cell (Surapu et al., 2014; Dikilitas et al., 2015).

The response of antioxidant enzymes in general to heavy metals and $\mathrm{Cd}$ can also vary in various tissues and among plant species (Zhang et al., 2009; Ovecka et al., 2014). The ROS caused by $\mathrm{Cd}$ toxicity can be detoxified via antioxidant system which plays an important role in the removal of ROS and provides tolerance to plants under abiotic 
stresses. Measuring antioxidant enzymes along with the metabolites could give crucial findings in phytoremediation studies.

Previous studies showed that Carpobrotus species showed great tolerance to a mixture of heavy metals including $\mathrm{Cd}, \mathrm{Cr}, \mathrm{Cu}, \mathrm{Mn}, \mathrm{Ni}, \mathrm{Pb}$ and $\mathrm{Zn}$ and was able to accumulate $\mathrm{Cd}$ in its shoots (Zhang et al., 2014, 2015). Halophyte species C. acinaciformis L. (Elands sourfig) is a fast growing, succulent perennial plant belonging to Azioaceae family. It is commonly inhabited in the Mediterranean area. It is resistant to harsh conditions such as salt and drought and multiple heavy metals (Zhang et al., 2016). We are in the search of finding new plant species showing high degree of tolerance to heavy metal stress such as $\mathrm{Cd}$. We established a novel test system to measure the level of tolerance system via measurement of DNA integrity and DNA health. The present study focused on Cd tolerance in $C$. acinaciformis plants via measuring biochemical and genetic parameters such as proline, protein, enzymes, DNA integrity, etc. to elucidate the toxicity of $\mathrm{Cd}$.

\section{Materials and Methods}

C. acinaciformis L. was selected as a model halophyte plant to observe the effects of $\mathrm{Cd}$ toxicity. The plants with visually similar biomass and equal length were carefully collected from the fields of Agricultural Faculty of Harran University, Turkey. The plants were exposed to eight different $\mathrm{Cd}$ concentrations (0-, 2.5-, 5-, 10-, 20-, 40-, 80- and $100 \mathrm{ppm}$ ) in hydroponic conditions. Treatments in each group were replicated four times. To maintain constant volume and concentration of the solution, $\mathrm{Cd}$ was added in proper amounts every other day along with the modified Arnon and Hoagland's nutrient solutions (Jasoni et al., 2002). The solutions during this period were changed twice every two weeks. At the end of the trial period, leaf samples were collected and washed with deionized water to remove excess dirt and the samples were stored at $-20{ }^{\circ} \mathrm{C}$ in a freezer followed by removal of excess water via filter paper. The samples were preserved there until used.

\section{Biochemical analysis methods}

Total chlorophyll (Chl- $a+\mathrm{Chl}-b)$ and carotenoid contents of $C$. acinaciformis were determined based on the method of Arnon (1949) with slight modifications (Dikilitas, 2003). Fresh leaf samples $(0.5 \mathrm{~g})$ were homogenized in a $10 \mathrm{~mL}$ acetone:water (80:20, $\mathrm{v}: \mathrm{v})$ mixture and filtered through Whatman No.2 filter paper then placed in the dark tubes. Chl- $a$ and Chl- $b$ of the plant samples were read at a UV microplate spectrophotometer (Epoch, SN: 1611187, made in USA) at 663 and $645 \mathrm{~nm}$, carotenoid contents of the leaves were measured at 480 and $510 \mathrm{~nm}$, respectively against $80 \%$ acetone blank. Total chlorophyll was calculated as $\mathrm{mg} \mathrm{L}^{-1}$ and expressed as $\mathrm{mg} \mathrm{g}^{-1} \mathrm{Fwt}$ (Eq. 1).

$$
\text { Total chlorophyll }\left(\mathrm{mg} \mathrm{g}^{-1}\right)=\frac{20.2 \times(\mathrm{A} 480)-8.02 \times(\mathrm{A} 510) \times \mathrm{V}}{1000} \times W
$$

where, A: Absorbance at specific wavelengths, W: Fresh weight to tissue extracted.

Proline (Pro) measurement was conducted according to the method of Bates et al. (1973) with slight modifications (Karakas et al., 2019). Leaf material (0.5 g) was homogenized in $3 \% \mathrm{w} / \mathrm{v}$ sulphosalicylic acid using a mortar and a pestle. The homogenate was filtered through Whatman No. 2 filter paper. Then, $2 \mathrm{~mL}$ of filtrate was mixed in a test tube with $2 \mathrm{~mL}$ of acid-ninhydrin reagent $(1.25 \mathrm{~g}$ of ninhydrin in $30 \mathrm{~mL}$ of glacial 
acetic acid and $20 \mathrm{~mL}$ of $6 \mathrm{~mol} \mathrm{~L}-1$ phosphoric acid) and boiled at $100{ }^{\circ} \mathrm{C}$ for one hour. The reaction was terminated in an ice bath. The reaction mixture was then extracted using $5 \mathrm{~mL}$ of toluene. The tubes were thoroughly shaken for $15-20$ seconds and left for $20 \mathrm{~min}$ at room temperature in order to achieve separation for two layers. The chromophore containing toluene was removed and allowed to warm to room temperature, and the absorbance of the solution was measured at $515 \mathrm{~nm}$ using a toluene blank. Proline concentration was determined using a calibration curve made with L-proline (SigmaAldrich 81202-06-4) and the results were expressed as $\mu \mathrm{mol} \mathrm{g}^{-1}$ Fwt.

The malondialdehyde (MDA) content was determined according to the method of Sairam and Saxena (2000) with slight modifications (Karakas et al., 2019). Leaf material $(0.5 \mathrm{~g})$ was homogenized in $10 \mathrm{ml}$ of $0.1 \%(\mathrm{w} / \mathrm{v})$ trichloroacetic acid (TCA) solution. The homogenate was centrifuged at $10,000 \mathrm{~g}$ for five minutes. Four $\mathrm{mL}$ of $20 \% \mathrm{v} / \mathrm{v}$ TCA containing $0.5 \% \mathrm{v} / \mathrm{v}$ thiobarbituric acid (TBA) was added to one mililiter of the supernatant. The mixture was incubated in boiling water for $30 \mathrm{~min}$, and the reaction was stopped by placing the reaction tubes in an ice bath. The mixture was centrifuged again at $10,000 \mathrm{~g}$ for $5 \mathrm{~min}$ and the absorbance of the supernatant was read at 532 and $600 \mathrm{~nm}$. Here, the MDA content of leaves is expressed as nmol g ${ }^{-1}$ Fwt, (Eq. 2).

$$
\operatorname{MDA}\left(\mathrm{nmol} \mathrm{g}^{-1}\right)=\frac{\text { Extract volume }(\mathrm{ml}) x\left[\frac{A_{532}-A_{600}}{155 \mathrm{mM}^{-1} \mathrm{~cm}^{-1}}\right]}{W(\mathrm{~g})} \times 10^{3}
$$

where, A: Absorbance at specific wavelengths, W: samples weight.

Hydrogen peroxide levels $\left(\mathrm{H}_{2} \mathrm{O}_{2}\right)$ were determined according to Velikova et al. (2000) with slight modifications (Karakas et al., 2019). Fresh plant tissue (0.5 g) was homogenized in an ice bath with $5 \mathrm{~mL} 0.1 \%(\mathrm{w}: \mathrm{v})$ TCA. The homogenate was centrifuged at $12,000 \mathrm{~g}$ for $15 \mathrm{~min}$ at $4{ }^{\circ} \mathrm{C}$ and $0.5 \mathrm{~mL}$ of the supernatant were added to $0.5 \mathrm{~mL}$ $10 \mathrm{mmol} \mathrm{L}^{-1}$ potassium phosphate buffer $\left(\mathrm{pH} \mathrm{7.0)}\right.$ and $1 \mathrm{~mL}$ of $1 \mathrm{~mol} \mathrm{~L}^{-1}$ potassium iodide. The absorbance was read at $390 \mathrm{~nm}$ using a UV microplate spectrophotometer (Epoch, SN: 1611187, made in USA). The $\mathrm{H}_{2} \mathrm{O}_{2}$ content was expressed as $\mu \mathrm{mol} \mathrm{g}^{-1}$ Fwt.

Catalase enzyme activity (CAT, E.C. 1.11.1.6) was determined by monitoring the decomposition of $\mathrm{H}_{2} \mathrm{O}_{2}$ according to the method of Milosevic and Slusarenko (1996) with slight modifications (Karakas et al., 2019). Fresh leaf tissue $(0.5 \mathrm{~g})$ was homogenized in $10 \mathrm{~mL}$ of $50 \mathrm{mmol} \mathrm{L}^{-1} \mathrm{Na}$-phosphate buffer solution, then $50 \mu \mathrm{L}$ of plant extract was added to a $2.95 \mathrm{~mL}\left(10 \mathrm{mmol} \mathrm{L}^{-1} \mathrm{H}_{2} \mathrm{O}_{2}, 50 \mathrm{mmol} \mathrm{L}^{-1} \mathrm{Na}\right.$-phosphate buffer and $4 \mathrm{mmol} \mathrm{L}^{-1}$ $\mathrm{Na}_{2}$ EDTA) reaction mixture and measured for 30 seconds at $240 \mathrm{~nm}$ with a UV microplate spectrophotometer (Epoch, SN: 1611187, made in USA). One CAT activity unit $(\mathrm{U})$ is defined as a change of 0.1 absorbance unit per minute. Activity is expressed as enzyme units per gram of Fwt.

Peroxidase enzyme activity (E.C.1.11.1.7) was determined according to the method of Cvikrova et al. (1994) with slight modifications (Karakas et al., 2019). For the analysis, $100 \mu \mathrm{L}$ of extract (obtained as above) was added to $3 \mathrm{~mL}$ of the reaction mixture (13 mmol L $\mathrm{m}^{-1}$ guaiacol, $5 \mathrm{mmol} \mathrm{L} \mathrm{H}_{2} \mathrm{O}_{2}$, and $50 \mathrm{mmol} \mathrm{L}^{-1} \mathrm{Na}$-phosphate, $\mathrm{pH}$ 6.5). The reaction was measured at $470 \mathrm{~nm}$ using a UV microplate spectrophotometer (Epoch, SN: 1611187, made in USA) at one-minute interval until $3^{\text {rd }}$ minute. One unit (U) of POX activity was defined as a change of 0.1 absorbance unit per minute at $470 \mathrm{~nm}$. Activity is expressed as enzyme units per gram of Fwt. 


\section{Cd ion content}

Cd content of leaves was determined according to the procedure of Walinga et al. (1989) with slight modifications. The homogenate obtained following filtration was analyzed by Inductively Coupled Plasma (ICP, Perkin Elmer).

\section{DNA fragmentation}

Genomic DNA was isolated from fresh leaves of $C$. acinaciformis according to the method of Ahrens and Seemüller (1992) and Surapu et al. (2014). Fresh leaf tissue (1 g) were homogenized in $4 \mathrm{~mL}$ of CTAB buffer $(2 \% \mathrm{w} / \mathrm{v}$ cetyltrimethylammonium bromide, $1.4 \mathrm{~mol} \mathrm{~L}^{-1} \mathrm{NaCl}, 0.2 \%$ 2- $\beta$-mercaptoethanol, $20 \mathrm{~mol} \mathrm{~L}^{-1}$ EDTA, $100 \mathrm{~mol} \mathrm{~L}^{-1}$ Tris- $\mathrm{HCl}$, $2 \%$ polyvinylpyrrolidone, $\mathrm{pH} 8.0$ ) and incubated at $65^{\circ} \mathrm{C}$ for $30 \mathrm{~min}$. An equal volume of chloroform-isoamyl alcohol (24:1) was added to the lysis buffer (CTAB), vigorously mixed for $1 \mathrm{~min}$ and centrifuged at $12,000 \mathrm{~g}$ for $10 \mathrm{~min}$. This step was repeated twice. The aqueous nucleic acid layer was transferred to a new tube and $2 / 3$ volumes of ice-cold isopropanol $\left(-20^{\circ} \mathrm{C}\right)$ was added and centrifuged for $10 \mathrm{~min}$ at $8,000 \mathrm{~g}$. The supernatant was discarded, and the pellet containing DNA was washed with $70 \%$ ethanol, vacuumdried and suspended in $50 \mu \mathrm{l}$ of Tris-EDTA (TE) buffer $\left(10 \mathrm{mmol} \mathrm{L} \mathrm{L}^{-1}-\mathrm{HCl}\right.$ and $0.1 \mathrm{mmol} \mathrm{L}^{-1}$ EDTA, pH 7.5). DNA fragmentation was analyzed following electrophoresis on a $1 \%$ agarose gel (Sigma, Aldrich) using 1xTris Acetate EDTA (TAE) buffer and a constant voltage of $85 \mathrm{~V}$ for $75 \mathrm{~min}$.

DNA was visualized by UV fluorescence after staining with ethidium bromide $\left(1 \mu \mathrm{g} \mathrm{mL}^{-1}\right)$ and the images of DNA bands were captured using an imaging system. The damaged DNA appeared as a ladder consisting of DNA fragments whereas intact DNA had high molecular weight and did not migrate very much in the gel (Karuppanapandian and Kim, 2013; Surapu et al., 2014).

\section{DNA damage in leaves}

The method of single cell gel electrophoresis (SCGE) which is also known as "Comet assay" was used to detect DNA damage in a single cell in leaves of $C$. acinaciformis induced by $\mathrm{Cd}$. The leaves were washed three times with deionized water, blotted dry with fitler paper and used in the comet assay immediatelly. All operations were conducted under dim or yellow light to avoid DNA damage induced by light. The leaves were placed in a $60-\mathrm{mm}$ Petri dish on ice and leaf was gently chooped into pieces in $250 \mu 1$ of cold phosphate buffered saline (PBS) $\left(130 \mathrm{mmol} \mathrm{L}^{-1} \mathrm{NaCl}, 7 \mathrm{mmol} \mathrm{L}-1 \mathrm{Na}_{2} \mathrm{HPO}_{4}, 3 \mathrm{mmol} \mathrm{L}^{-1}\right.$ $\mathrm{NaH}_{2} \mathrm{PO}_{4}, 50 \mathrm{mmol} \mathrm{L}^{-1}$ EDTA, pH 7.5) in just $20 \mathrm{~s}$. The pieces were washed in the buffer by repeated pipetting using a micropipette. The suspended solution $(0.15 \mathrm{~mL})$ containing nuclei was mixed with $0.2 \mathrm{~mL}$ of a solution containing $1 \%$ low melting point agarose (LMPA) (Sigma, Aldrich) in PBS at $37^{\circ} \mathrm{C}$. A drop of the nuclei/agarose mixture was placed onto a pre-coated glass slide with normal melting point agarose (NMPA) and a coverslip was placed over the suspension. The slides were kept at $4{ }^{\circ} \mathrm{C}$ in the fridge for $5 \mathrm{~min}$, after gel formation, the coverslip was removed and the slides were put in freshly prepared cold alkaline buffer ( $300 \mathrm{mmol} \mathrm{L}{ }^{-1} \mathrm{NaOH}, 1$ mmol L-1 $\left.\mathrm{Na}_{2} \mathrm{EDTA}, \mathrm{pH}>13\right)$ in darkness at $4{ }^{\circ} \mathrm{C}$ to allow the DNA to denature for 15 minutes (Kassaye et al., 2013). The total time from the beginning of slicing to transfer of slides was about 6-7 min. After this stage, electrophoresis was conducted at $4{ }^{\circ} \mathrm{C}$ in the alkaline buffer for $15 \mathrm{~min}$ at $25 \mathrm{~V}$, $300 \mathrm{~mA}$. After electrophoresis, the slides were neutralized with a cold neutralization buffer $\left(0.4 \mathrm{~mol} \mathrm{~L}^{-1}\right.$ Tris-HCl, $\left.\mathrm{pH} 7.5\right)$ at $4{ }^{\circ} \mathrm{C}$ for $5 \mathrm{~min}$ then dipped in $95 \%$ ethanol to 
facilitate drying. After drying at room temperature, each slide was stained with $70 \mu 1$ ethidium bromide $\left(2 \mu \mathrm{g} \mathrm{mL}^{-1}\right.$ in distilled water $\left.\mathrm{H}_{2} \mathrm{O}\right)$. The stained DNA was viewed using a fluorescent microscope (Olympus, Japan) at $400 \mathrm{x}$ magnificitation provided with epifluorescence and equipped with a rhodamine filter (excitation wavelength $546 \mathrm{~nm}$; barrier $580 \mathrm{~nm}$ ). The damaged DNA has a similar structure to that of the comet. Randomly chosen comets were scored using "comet assay software program" (CASP) (Konca et al., 2003). Fifty comets representing each cells were scored per plant and the level of DNA damage was expressed as the percentage of DNA in the tail (\% tail DNA) (Dikilitas et. al., 2009).

\section{Statistical analysis}

Data were statistically analysed by one-way analysis of variance (ANOVA) using the SPSS software program (Version 22.0). Duncan's Multiple Range Test was performed at a significance level of $P \leq 0.05$ to separate treatment means for each measured parameter.

\section{Result}

Biochemical responses such as total chlorophyll, carotenoid content, proline, MDA, $\mathrm{H}_{2} \mathrm{O}_{2}$, POX and CAT in leaves of $C$. acinaciformis were determined under differing concentrations of cadmium $\left(\mathrm{CdNO}_{3}\right)$.

Increased $\mathrm{Cd}$ concentrations adversely affected the pigment formation, the pigment contents such as chlorophyll and carotenoid significantly declined after 40 ppm cadmium dose. With respect to the carotenoid content, increased Cd concentrations led to increased carotenoid content up to $40 \mathrm{ppm}$ dose level indicating a defensive strategy of the halophyte $C$. acinaciformis. Therefore, Cd doses up to $40 \mathrm{ppm}$ were not suppressive to chlorophyll and carotenoid. However, after $40 \mathrm{ppm}$ Cd doses, a remarkable decline in both chlorophyll and carotenoid contents were evident (Figure 1A,B, Table 1).

Again, proline content of $C$. acinaciformis gradually increased up to $40 \mathrm{ppm} \mathrm{CdNO}_{3}$ dose $\left(3.53 \mu \mathrm{mol} \mathrm{g}^{-1}\right.$ Fwt, Figure 2, Table 1), then, the proline content of $C$. acinaciformis showed a gradual decline. Although proline level declined at $60 \mathrm{ppm} \mathrm{CdNO}_{3}$ concentration, this level, however, was not statistically different from those of proline levels at 20 and $40 \mathrm{ppm} \mathrm{CdNO}_{3}$. Proline contents at 80 and $100 \mathrm{ppm}$ were remarkably low as compared to that of $40 \mathrm{ppm}$, which was the threshold level for proline content. It is important to note that $\mathrm{Cd}$ was not suppressive to proline synthesis up to $40 \mathrm{ppm}$ indicating that synthesis of proline was responsive against $\mathrm{Cd}$ toxicity. However, a gradual decline was observed thereafter and the synthesis of proline was minimal at 80 and $100 \mathrm{ppm} C \mathrm{Cd}$ concentrations. This clearly showed that $C$. acinaciformis plant was not successful to synthesize proline at $80 \mathrm{ppm} \mathrm{Cd} \mathrm{level} \mathrm{to} \mathrm{reduce} \mathrm{the} \mathrm{toxic} \mathrm{effects} \mathrm{of} \mathrm{Cd}$.

When the stress markers were examined, both MDA and $\mathrm{H}_{2} \mathrm{O}_{2}$ accumulation in leaves of $C$. acinaciformis showed similar trends in which the stress markers, $\mathrm{MDA}, \mathrm{H}_{2} \mathrm{O}_{2}$, were evident at $10 \mathrm{ppm} \mathrm{CdNO}_{3}$ concentrations. Increasing concentrations led to further increases of MDA and $\mathrm{H}_{2} \mathrm{O}_{2}$ accumulation, (Figure 3a,b, Table 1). Accumulation of MDA and $\mathrm{H}_{2} \mathrm{O}_{2}$ showed plateau between 60 and 100 ppm $\mathrm{CdNO}_{3}$ indicating that halophyte $C$. acinaciformis tolerated $100 \mathrm{ppm} \mathrm{Cd}$ as it tolerated $60 \mathrm{ppm} \mathrm{CdNO}_{3}$. This was negatively corelated with the accumulation of proline as $C$. acinaciformis exhibited decreasing proline accumulation between 60 and $100 \mathrm{ppm} \mathrm{Cd}$ doses. 


$$
-2655-
$$

(A)

\section{C. acinaciformis}

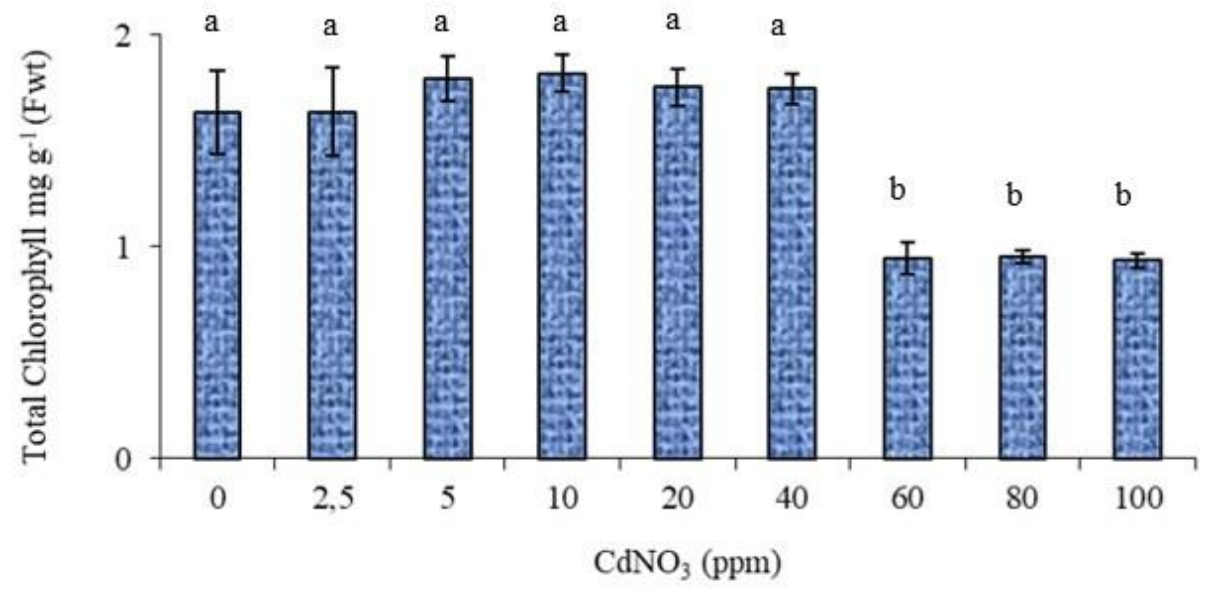

(B)

C. acinaciformis

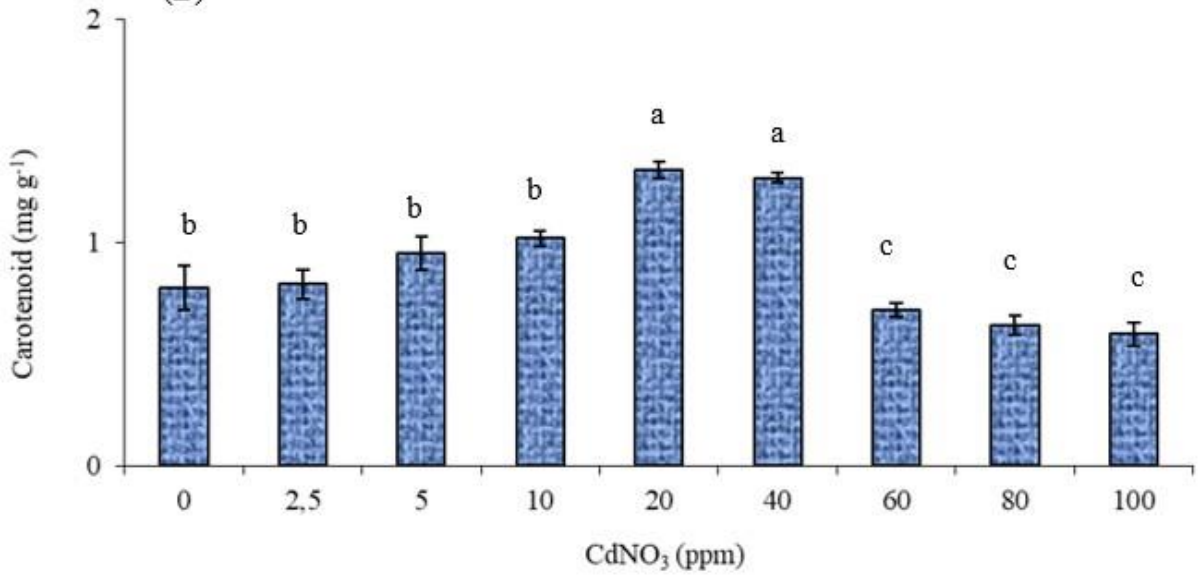

Figure 1. Total Chlorophyll (A) and Carotenoid (B) contents in leaves of C. acinaciformis at different $\mathrm{CdNO}_{3}$ stress. Bars indicate the means of the four replicates \pm standard error. Letters indicate significant differences from one another according to Duncan's Multiple Range Test at $P \leq 0.05$

C. acinaciformis

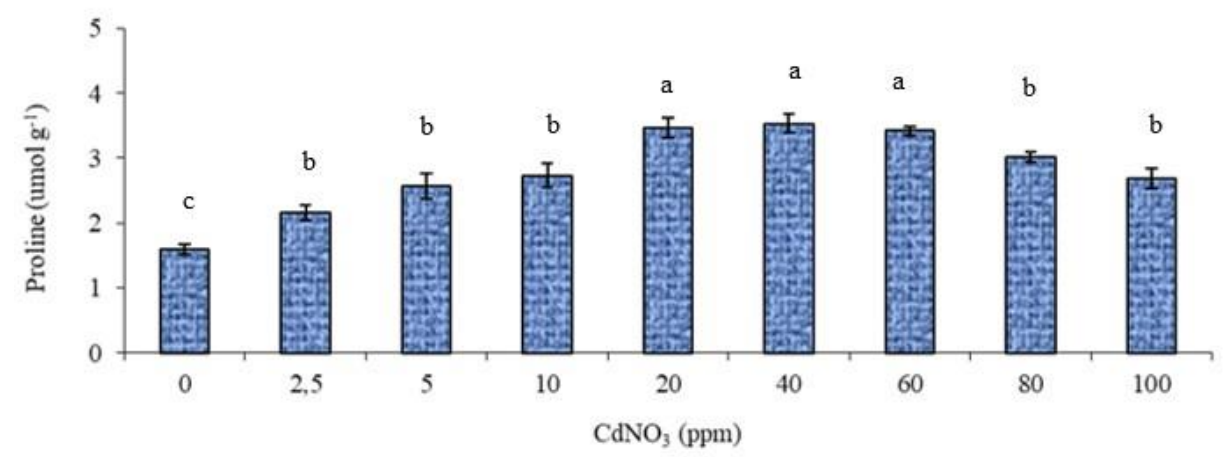

Figure 2. Proline contents in leaves of C. acinaciformis at different $\mathrm{CdNO}_{3}$ stress. Letters indicate the means of the four replicates \pm standard error. Bars indicate significant differences from one another according to Duncan's Multiple Range Test at $P \leq 0.05$ 


$$
-2656-
$$

Table 1. Statistically analyses of Data using ANOVA

\begin{tabular}{|c|c|c|c|c|c|}
\hline Parameters & $\mathrm{CdNO}_{3}(\mathrm{ppm})$ & $\mathbf{n}$ & Mean \pm S.E & $\mathbf{F}$ & $\mathbf{p}$ \\
\hline Total Chlorpohyll & $\begin{array}{c}0 \\
2.5 \\
5 \\
10 \\
20 \\
40 \\
60 \\
80 \\
100 \\
\text { Total } \\
\end{array}$ & $\begin{array}{c}4 \\
4 \\
4 \\
4 \\
4 \\
4 \\
4 \\
4 \\
4 \\
36 \\
\end{array}$ & $\begin{array}{c}1.63 \pm 0.19 \mathrm{a} \\
1.64 \pm 0.20 \mathrm{a} \\
1.79 \pm 0.10 \mathrm{a} \\
1.82 \pm 0.09 \mathrm{a} \\
1.75 \pm 0.08 \mathrm{a} \\
1.74 \pm 0.07 \mathrm{a} \\
0.95 \pm 0.07 \mathrm{~b} \\
0.95 \pm 0.03 \mathrm{~b} \\
0.94 \pm 0.03 \mathrm{~b} \\
1.47 \pm 0.07 \\
\end{array}$ & 47.89 & 0.00 \\
\hline Carotenoid & $\begin{array}{c}0 \\
2.5 \\
5 \\
10 \\
20 \\
40 \\
60 \\
80 \\
100 \\
\text { Total } \\
\end{array}$ & $\begin{array}{c}4 \\
4 \\
4 \\
4 \\
4 \\
4 \\
4 \\
4 \\
4 \\
36 \\
\end{array}$ & $\begin{array}{c}0.79 \pm 0.09 \mathrm{~b} \\
0.81 \pm 0.07 \mathrm{~b} \\
0.95 \pm 0.03 \mathrm{~b} \\
1.02 \pm 0.04 \mathrm{~b} \\
1.33 \pm 0.02 \mathrm{a} \\
1.29 \pm 0.02 \mathrm{a} \\
0.70 \pm 0.03 \mathrm{c} \\
0.63 \pm 0.05 \mathrm{c} \\
0.59 \pm 0.05 \mathrm{c} \\
0.90 \pm 0.05 \\
\end{array}$ & 23.08 & 0.00 \\
\hline Proline & $\begin{array}{c}0 \\
2.5 \\
5 \\
10 \\
20 \\
40 \\
60 \\
80 \\
100 \\
\text { Total } \\
\end{array}$ & $\begin{array}{c}4 \\
4 \\
4 \\
4 \\
4 \\
4 \\
4 \\
4 \\
4 \\
36 \\
\end{array}$ & $\begin{array}{c}1.60 \pm 0.08 \mathrm{c} \\
2.17 \pm 0.12 \mathrm{~b} \\
2.57 \pm 0.19 \mathrm{~b} \\
2.74 \pm 0.18 \mathrm{~b} \\
3.46 \pm 0.16 \mathrm{a} \\
3.53 \pm 0.15 \mathrm{a} \\
3.42 \pm 0.06 \mathrm{a} \\
3.01 \pm 0.08 \mathrm{~b} \\
2.69 \pm 0.16 \mathrm{~b} \\
2.80 \pm 0.11 \\
\end{array}$ & 20.60 & 0.00 \\
\hline MDA & $\begin{array}{c}0 \\
2.5 \\
5 \\
10 \\
20 \\
40 \\
60 \\
80 \\
100 \\
\text { Total } \\
\end{array}$ & $\begin{array}{c}4 \\
4 \\
4 \\
4 \\
4 \\
4 \\
4 \\
4 \\
4 \\
36 \\
\end{array}$ & $\begin{array}{c}3.22 \pm 0.24 \mathrm{c} \\
4.12 \pm 0.32 \mathrm{c} \\
5.82 \pm 0.36 \mathrm{c} \\
15.82 \pm 2.11 \mathrm{~b} \\
17.14 \pm 1.42 \mathrm{~b} \\
17.69 \pm 1.36 \mathrm{~b} \\
20.85 \pm 1.74 \mathrm{a} \\
22.53 \pm 1.12 \mathrm{a} \\
22.87 \pm 1.36 \mathrm{a} \\
14.45 \pm 1.32\end{array}$ & 38.41 & 0.00 \\
\hline $\mathrm{H}_{2} \mathrm{O}_{2}$ & $\begin{array}{c}0 \\
2.5 \\
5 \\
10 \\
20 \\
40 \\
60 \\
80 \\
100 \\
\text { Total } \\
\end{array}$ & $\begin{array}{c}4 \\
4 \\
4 \\
4 \\
4 \\
4 \\
4 \\
4 \\
4 \\
36 \\
\end{array}$ & $\begin{array}{c}2.93 \pm 0.27 \mathrm{c} \\
4.05 \pm 0.13 \mathrm{c} \\
5.49 \pm 0.13 \mathrm{c} \\
16.62 \pm 1.07 \mathrm{~b} \\
17.98 \pm 1.26 \mathrm{~b} \\
19.54 \pm 2.05 \mathrm{a} \\
22.23 \pm 1.24 \mathrm{a} \\
22.35 \pm 1.02 \mathrm{a} \\
24.14 \pm 0.44 \mathrm{a} \\
15.04 \pm 1.39 \\
\end{array}$ & 66.22 & 0.00 \\
\hline POX & $\begin{array}{c}0 \\
2.5 \\
5 \\
10 \\
20 \\
40 \\
60\end{array}$ & $\begin{array}{l}4 \\
4 \\
4 \\
4 \\
4 \\
4 \\
4\end{array}$ & $\begin{array}{l}0.98 \pm 0.12 \mathrm{c} \\
1.10 \pm 0.07 \mathrm{c} \\
1.26 \pm 0.06 \mathrm{c} \\
1.55 \pm 0.18 \mathrm{c} \\
3.43 \pm 0.13 \mathrm{a} \\
3.74 \pm 0.17 \mathrm{a} \\
1.93 \pm 0.14 \mathrm{~b}\end{array}$ & 63.96 & 0.00 \\
\hline
\end{tabular}




\begin{tabular}{|c|c|c|c|c|c|}
\hline Parameters & $\mathrm{CdNO}_{3}(\mathrm{ppm})$ & $n$ & Mean \pm S.E & $\mathbf{F}$ & $\mathbf{p}$ \\
\hline & 80 & 4 & $2.11 \pm 0.08 \mathrm{~b}$ & & \\
\hline & 100 & 4 & $1.90 \pm 0.09 \mathrm{~b}$ & & \\
\hline & Total & 36 & $1.99 \pm 0.16$ & & \\
\hline \multirow{10}{*}{ CAT } & 0 & 4 & $0.43 \pm 0.03 \mathrm{c}$ & \multirow{10}{*}{33.48} & \multirow{10}{*}{0.00} \\
\hline & 2.5 & 4 & $0.46 \pm 0.03 \mathrm{c}$ & & \\
\hline & 5 & 4 & $0.61 \pm 0.05 \mathrm{c}$ & & \\
\hline & 10 & 4 & $0.73 \pm 0.11 \mathrm{c}$ & & \\
\hline & 20 & 4 & $1.95 \pm 0.20 \mathrm{a}$ & & \\
\hline & 40 & 4 & $1.81 \pm 0.14 \mathrm{a}$ & & \\
\hline & 60 & 4 & $1.22 \pm 0.03 \mathrm{~b}$ & & \\
\hline & 80 & 4 & $1.20 \pm 0.01 \mathrm{~b}$ & & \\
\hline & 100 & 4 & $1.02 \pm 0.06 \mathrm{~b}$ & & \\
\hline & Total & 36 & $1.05 \pm 0.09$ & & \\
\hline \multirow{10}{*}{ Leaf $\mathrm{Cd}$ contents } & 0 & 4 & $0.01 \pm 0.01 \mathrm{f}$ & \multirow{10}{*}{765.16} & \multirow{10}{*}{0.00} \\
\hline & 2.5 & 4 & $1.25 \pm 0.11 \mathrm{f}$ & & \\
\hline & 5 & 4 & $2.15 \pm 0.15 \mathrm{f}$ & & \\
\hline & 10 & 4 & $4.78 \pm 0.19 \mathrm{e}$ & & \\
\hline & 20 & 4 & $13.14 \pm 0.85 \mathrm{~d}$ & & \\
\hline & 40 & 4 & $29.84 \pm 0.64 \mathrm{c}$ & & \\
\hline & 60 & 4 & $38.24 \pm 1.10 \mathrm{~b}$ & & \\
\hline & 80 & 4 & $40.12 \pm 1.15 b$ & & \\
\hline & 100 & 4 & $65.77 \pm 1.29 \mathrm{a}$ & & \\
\hline & Total & 36 & $21.70 \pm 3.68$ & & \\
\hline \multirow{10}{*}{ DNA Damage } & 0 & 4 & $7.22 \pm 0.08 \mathrm{c}$ & \multirow{10}{*}{40.25} & \multirow{10}{*}{0.00} \\
\hline & 2.5 & 4 & $7.46 \pm 0.12 \mathrm{c}$ & & \\
\hline & 5 & 4 & $7.68 \pm 0.16 \mathrm{c}$ & & \\
\hline & 10 & 4 & $7.73 \pm 0.19 \mathrm{c}$ & & \\
\hline & 20 & 4 & $8.26 \pm 0.37 \mathrm{c}$ & & \\
\hline & 40 & 4 & $9.11 \pm 0.01 \mathrm{c}$ & & \\
\hline & 60 & 4 & $12.24 \pm 1.21 \mathrm{~b}$ & & \\
\hline & 80 & 4 & $13.68 \pm 0.97 \mathrm{~b}$ & & \\
\hline & 100 & 4 & $17.95 \pm 0.68 \mathrm{a}$ & & \\
\hline & Total & 36 & $10.15 \pm 0.62$ & & \\
\hline
\end{tabular}

*Different letters indicate significant differences from one another according to Duncan's Multiple Range Test at $\mathrm{P} \leq 0.05$

When antioxidant enzymes such as POX and CAT were evaluated, a similar trend to those of proline and carotenoid was observed in that both POX and CAT gave increased responses both at 20 and $40 \mathrm{ppm} \mathrm{CdNO}_{3}$ doses, (Figure 4a,b, Table 1). However, declining trends in both enzymes were more apparent.

Impact of enzymes between 0-10 ppm or 60-100 ppm was low when compared to those of concentrations between 20-40 ppm $\mathrm{CdNO}_{3}$ levels. The results showed that the antioxidant mechanism gave the highest response between 20 and $40 \mathrm{ppm} \mathrm{CdNO}_{3}$ level, thereafter, the antioxidant response including enzymatic and non-enzymatic responses were decreased. This clearly showed that the defence mechanisms of $C$. acinaciformis plant broke down and did not function properly. It is important to note that following $60 \mathrm{ppm} \mathrm{Cd}$ toxicity in which the defence mechanism was minimized in the following section.

Apart from biochemical responses, molecular responses along with the accumulation of $\mathrm{Cd}$ in leaves of $C$. acinaciformis were evaluated upon exposure to various $\mathrm{CdNO}_{3}$ concentrations. As the concentration of $\mathrm{CdNO}_{3}$ increased, C. acinaciformis leaves accumulated increasing amount of $\mathrm{Cd}$ in their leaves. 

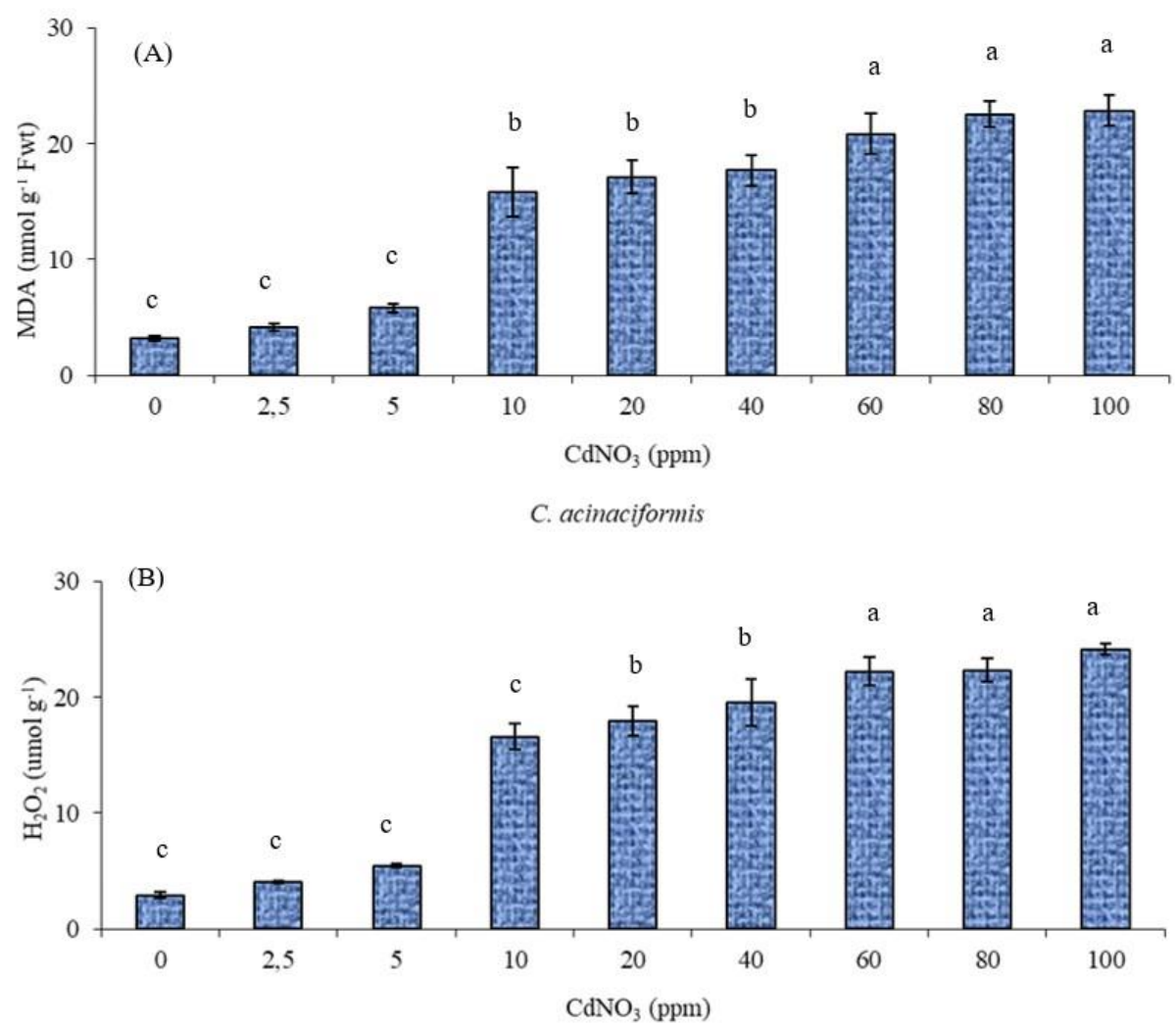

Figure 3. $\mathrm{MDA}(\mathrm{A})$ and $\mathrm{H}_{2} \mathrm{O}_{2}(\mathrm{~B})$ contents in leaves of $\mathrm{C}$. acinaciformis at different $\mathrm{CdNO}_{3}$ stress. Letters indicate the means of the four replicates \pm standard error. Bars indicate significant differences from one another according to Duncan's Multiple Range Test at $P \leq 0.05$

The higher the concentration of $\mathrm{CdNO}_{3}$ led to more accumulation of $\mathrm{Cd}$ in the leaves of $C$. acinaciformis. When DNA fragmentation was analysed through $1 \%$ agarose gel, the first sign of DNA fragmentation was evident at $5 \mathrm{ppm} \mathrm{CdNO}_{3}$ concentrations. Then, increasing concentration of Cd led to increased DNA fragmentation (Figure 5). At 5 ppm and above Cd concentrations, DNA fragmentations were evident both at 250 and $2000 \mathrm{bp}$. However, more fragments were visible at $250 \mathrm{bp}$ DNA molecule. It is evident that at 80 and $100 \mathrm{ppm}$ Cd concentrations, DNA fragments were more pronounced being at 250 and $500 \mathrm{bp}$. Since DNA fragmentation was performed on total DNA of leaves, it is possible that highly damaged DNA in a cell of leaves might contribute to increase of DNA damage in leaf samples. Therefore, DNA damage was also assessed by performing in a single cell to determine the condition of DNA. The results showed that the damage caused by $\mathrm{CdNO}_{3}$ was insignificant up to $40 \mathrm{ppm}$ dose, then a slightly increased DNA damage was evident at $60 \mathrm{ppm}$ dose, then 80 and $100 \mathrm{ppm}$ doses of $\mathrm{CdNO}_{3}$ led to highly significant DNA damages.

It is important to note that the tolerance of $\mathrm{CdNO}_{3}$ toxicity by $C$. acinaciformis was found consistent with the antioxidant enzyme responses in which the halophyte plant gave remarkable responses at $40 \mathrm{ppm} \mathrm{CdNO}_{3}$. However, $60 \mathrm{ppm}$ and above concentrations of $\mathrm{CdNO}_{3}$ significantly reduced chlorophyll and carotenoid contents and other enzymatic and non-enzymatic responses and the stress metabolites such as MDA and $\mathrm{H}_{2} \mathrm{O}_{2}$ were remarkably accumulated at these concentrations. 

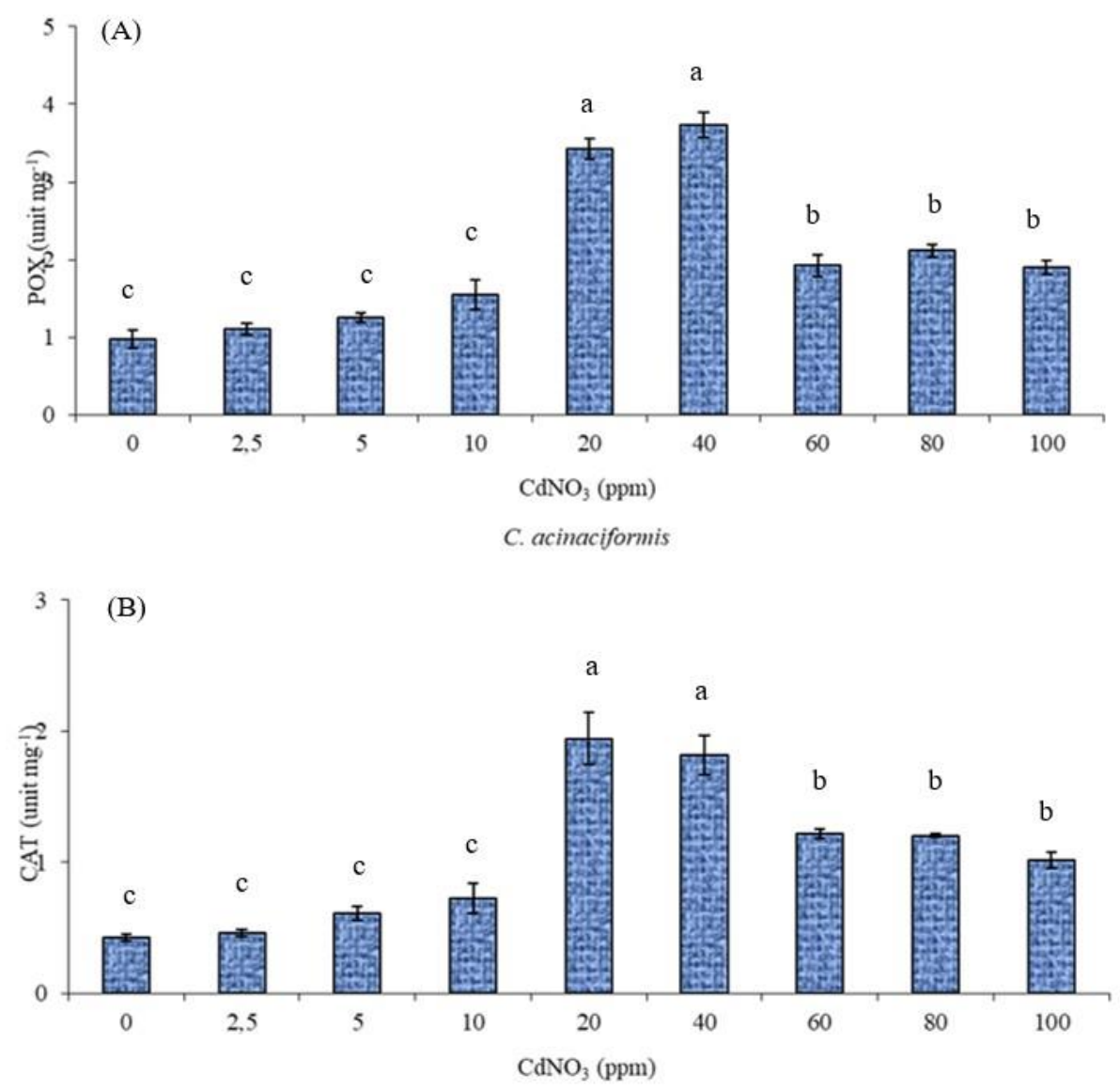

Figure 4. $P O X(A)$ and $C A T(B)$ contents in leaves of $C$. acinaciformis at different $\mathrm{CdNO}_{3}$ stress. Letters indicate the means of the four replicates \pm standard error. Letters indicate significant differences from one another according to Duncan's Multiple Range Test at $P \leq 0.05$

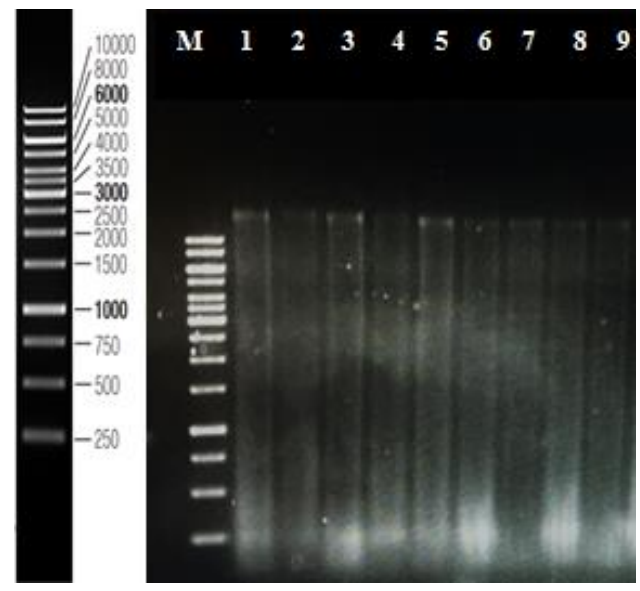

Figure 5. DNA fragmentation analysis of $C$. acinaciformis under differing $\mathrm{CdNO}_{3}$ concentrations, Lanes (M-9): M: marker $10 \mathrm{~kb}$ standard molecular weight marker, 1: 0 ppm, 2: 2.5 ppm, 3: 5 ppm, 4: 10 ppm, 5: 20 ppm, 6:40 ppm, 7: 60 ppm, 8: 80 ppm, 9: 100 ppm $\mathrm{CdNO}_{3}$ stress. DNA of C. acinaciformis was separated through 1\% agarose gel and visualized under UV fluorescence using ethidium bromide. Arrows show fragmented DNA molecules at different band sizes 


$$
-2660-
$$

Upon exposure to Cd toxicity, C. acinaciformis leaves accumulated significant amount of $\mathrm{Cd}$ ions. The highest $\mathrm{Cd}$ accumulation was $65.77 \mathrm{mg} \mathrm{kg}^{-1}$ at $100 \mathrm{ppm} \mathrm{Cd}$ levels. Assessment of DNA damage caused by $\mathrm{Cd}$ showed that $C$. acinaciformis did not show any dose-response increased DNA damage up to $60 \mathrm{ppm}$ Cd levels (Figure 6A,B, Table 1).
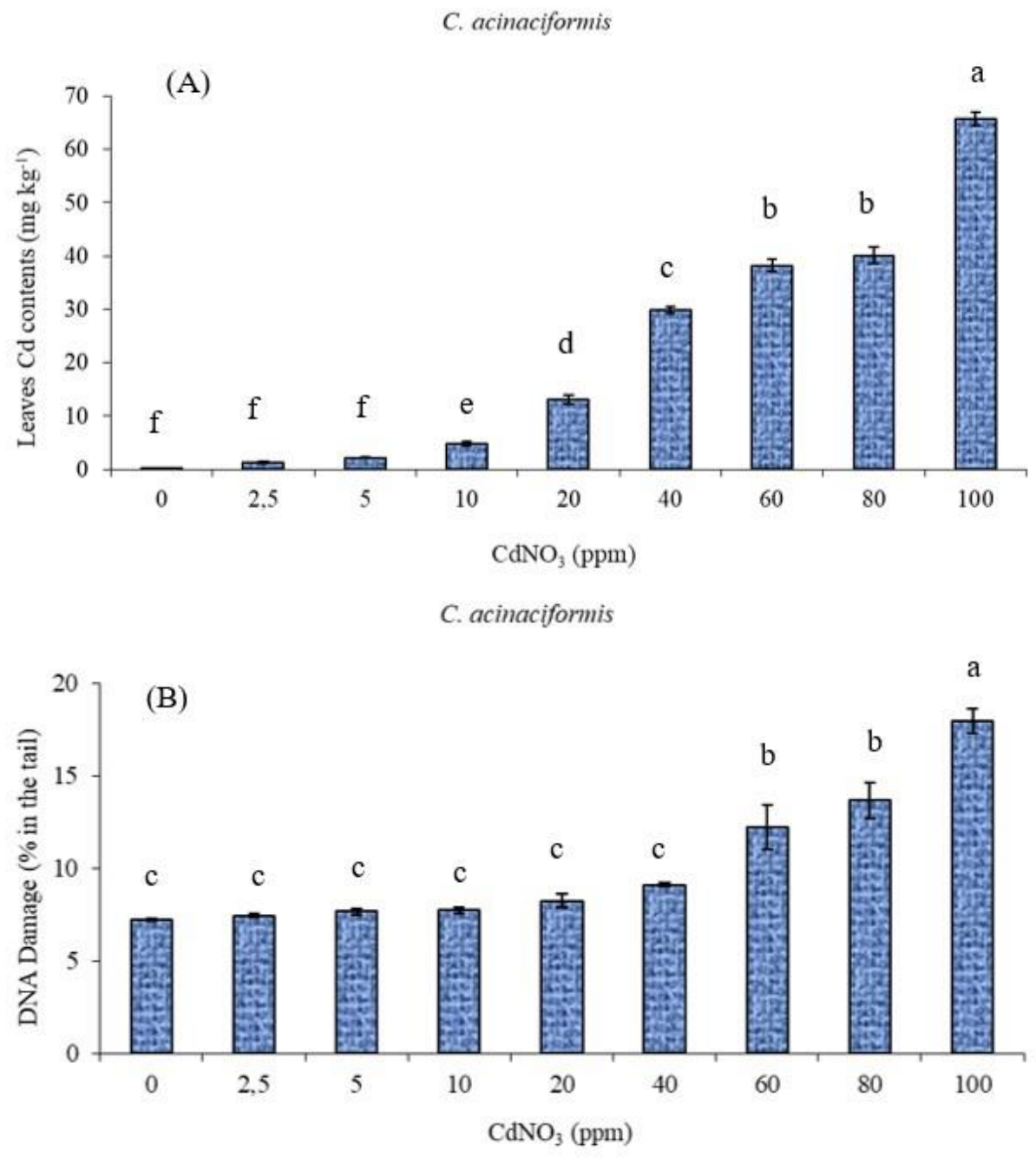

Figure 6. Cd ion contets (a) and DNA damage (b) in leaves of $C$. acinaciformis at different $\mathrm{CdNO}_{3}$ stress. Bars indicate the means of the four replicates \pm standard error. Letters indicate significant differences from one another according to Duncan's Multiple Range Test at $P \leq 0.05$

It is clear that a significant amount of $\mathrm{CdNO}_{3}$ accumulation in leaves led to not only biochemical disturbances but also molecular mechanisms were disturbed as shown by DNA fragmentation through gel electrophoresis and DNA damages via comet assay. It could be pointed out that the tolerance capacity of DNA of cells positively correlated with the biochemical responses of the cell. However, DNA molecule was found much stronger and resistant to Cd toxicity in terms of tail DNA damage \% and DNA fragment analysis. Therefore, it could be said that recovery of a cell in plants could totally depend on the integrity and health status of DNA. If DNA is not highly damaged, tolerance to stress could well be achieved. 


\section{Discussion}

A great number of studies have shown that the major sites of action for $\mathrm{Cd}$ are photosynthetic pigments, particularly the biosynthesis of chlorophyll (Guo et al., 2016; Paunov et al., 2018) and carotenoids (Zhang et al., 2020). Cd ions have been known to affect the structure and function of chloroplasts in many plant species such as Pisum sativum L. (Sandalio et al., 2001), Spinacea oleracea (Fagioni et al., 2009), Beta vulgaris (Basa et al., 2014), Triticum aestivum (Abedi and Mojiri, 2020). It is important to note that the halophyte still synthesized a remarkable content of carotenoids and chlorophyll between 60-100 ppm Cd dose levels in which the most glycophytes or tolerant plants such as tomato, pepper, wheat, vegetables show sensitivity. At higher doses, it could have serious effects and lead to death of crop plants. Although halophytes are more tolerant to abiotic stresses than those of glycophytes, however, heavy metal stress could have serious adverse effects on halophytes. Determination of level of tolerance of halophytes to heavy metal stress is important if those plants are aimed to be used for the purpose of cleaning up soils from heavy metals or used as companion plants with the crop plants. We determined that $C$. acinaciformis plants showed great declines at $60 \mathrm{ppm}$ and above $\mathrm{Cd}$ concentrations. the synthesized pigments were still enough and enabled the plant green colour. Although the halophyte plant was not able to synthesize sufficient amounts of chlorophyll and carotenoids as those of plants grown in control conditions, however, it was noticed that the synthesized pigments were still enough and enabled the plant green colour.

Proline is an adaptive response in plants exposed to a stressful environment. Proline accumulation appeared to be a suitable indicator of Cd stress. In this study, proline level in C. acinaciformis increased significantly following exposure to 2.5-, 5-,10-, 20-, 40-, 60-, 80-, and $100 \mathrm{ppm} \mathrm{CdNO}_{3}$ toxicity. Although the synthesis of proline started to decline at $60 \mathrm{ppm} \mathrm{Cd}$ doses, the remarkable reduction was evident at $80 \mathrm{ppm}$ Cd dose indicating that the build-up of defence metabolites was still active at $80 \mathrm{ppm} \mathrm{Cd}$ dose level. A similar study reported that tobacco cells exposed to Cd treatment accumulated high levels of proline and proline accumulation alleviated the inhibitory effects of $\mathrm{Cd}$ in tobacco cell (Islam et al., 2009; Zouari et al., 2016). For maintaining cell turgidity, plants are able to accumulate osmolytes such as proline, soluble protein, and ions under Cd stress (Cao et al., 2014). Proline stability of the sub-cellular structures by scavenging free radicals and modulating cellular homeostasis (Kour and Asthir, 2015).

$\mathrm{Cd}$ is a non-redox metal unable to perform single electron transfer reactions, and does not produce ROS such as the superoxide anion $\left(\mathrm{O}_{2}^{-}\right)$, singlet oxygen $\left({ }^{1} \mathrm{O}_{2}\right)$, hydrogen peroxide $\left(\mathrm{H}_{2} \mathrm{O}_{2}\right)$, and hydroxyl radical $\left(\mathrm{OH}^{-}\right)$, but generates oxidative stress by interfering with the antioxidant defence system (Benavides et al., 2005; Smeets et al., 2008; Das and Roychoudhury, 2014). Accumulation of stress metabolites started as early as at $2.5 \mathrm{ppm}$ $\mathrm{Cd}$ dose and increased thereafter. The remarkable build-up of stress metabolites started at $10 \mathrm{ppm} \mathrm{Cd}$ dose. At $60 \mathrm{ppm} \mathrm{Cd}$ dose, a significant accumulation of stress metabolites was evident, Figure 3. Increasing concentrations of Cd further up to $100 \mathrm{ppm} \mathrm{Cd}$ dose did not increase the build-up of stress metabolites. This was clearly reflected with the fact that the activities of antioxidant enzymes were minimal at $60 \mathrm{ppm} \mathrm{Cd}$ dose and increasing concentrations of $\mathrm{Cd}$ further up to $100 \mathrm{ppm}$ did not increase the level of antioxidant enzymes (POX and CAT), Figure 4. In our findings, POX and CAT antioxidant enzymes increased up to $40 \mathrm{ppm}$ Cd concentration, then slightly decreased. A similar finding was made by Yilmaz and Parlak (2011) who reported that the tolerance of Groenlandia densa to Cd stress was partially due to the high activity of CAT. It is important to note that here 
the accumulation of stress metabolites was in parallel with the synthesis of antioxidant enzymes. Reduction in the synthesis of antioxidant enzymes at and above $60 \mathrm{ppm} \mathrm{Cd}$ dose was accordance with the accumulation of stress metabolites such as MDA and $\mathrm{H}_{2} \mathrm{O}_{2}$.

Although the concentration of $\mathrm{Cd}$ increased and the higher amount of concentration of $\mathrm{Cd}$ increased and the higher amount of $\mathrm{Cd}$ was taken up by the halophyte plants, Figure 6 , and resulted in increased DNA damages via shown by DNA fragment analysis and Comet assay, the halophyte plant $C$. acinaciformis was not able to synthesize antioxidant enzymes higher than that of $60 \mathrm{ppm} \mathrm{Cd}$ dose at 80 and $100 \mathrm{ppm} \mathrm{Cd}$ doses. At those concentrations, no more stress metabolites were accumulated either. We suggest that the accumulation of stress metabolites totally depends on the defence metabolism available. It has been known that ROS damages in plants involve lipid peroxidation, protein oxidation, and DNA damage. Cd produced an enhancement of lipid peroxidation in bean (Chaoui et al., 1997), sunflower (Gallego et al., 1996), and maize and pea plants (LozanoRodriguez et al., 1997). DNA damage caused by Cd involved the destruction of nucleic acids, cell membrane, lipids, and proteins; reduction of protein synthesis; and damage of photosynthetic proteins, which affects growth and development of the whole organism. DNA damage has also been defined via the determination of the frequency of abnormalities such as fragments, single and double bridges, and stickiness (Gill and Tuteja, 2010; Noor et al., 2018). It is clear that DNA breaks occurred much faster and at higher impact at 60 and above concentrations of $\mathrm{Cd}$ without accumulating stress metabolites and defence enzymes. So, we could conclude that level of Cd dose that causes significant DNA damages is the threshold level for plants that no recovery should be expected unless additional help is enabled.

\section{Conclusion}

C. acinaciformis plant could well be used to remediate Cd-contaminated sites. To determine the removal $\mathrm{Cd}$ capacity of $C$. acinaciformis, we measured the accumulation of $\mathrm{Cd}$ in leaves. C. acinaciformis plants accumulated significant amount of $\mathrm{Cd}$ up to $60 \mathrm{ppm}$ without exerting significant stress symptoms. At high $\mathrm{Cd}$ concentrations, significant amounts of pigment loss along with the increase of oxidant molecules and decrease of antioxidant enzymes were evident. Cd toxicity results in chromosomal aberrations, DNA stand breaks, sister chromatid exchange in DNA molecules. Its toxicity involves depletion of antioxidant molecules and enhances ROS. However, at high doses, it could cause direct DNA damages without exerting oxidative stress as shown in this study. DNA integrity and health also proved that the nuclear elements were more resistant to the toxicity of $\mathrm{Cd}$ as compared to those of metabolites. Measuring metabolites is important to determine the tolerance level of the halophyte, however, molecular approaches to determine the possible highest level of tolerance of the halophyte to $\mathrm{Cd}$ toxicity is of great significance. We conclude that the roots of halophyte $C$. acinaciformis plant has ability to remove $\mathrm{Cd}$ from contaminated sites and are a strong candidate to clean up the soils contaminated with heavy metals.

Acknowledgments. Biochemical and DNA analyses were performed in the laboratory of Plant Protection under the supervision of Dr. Murat Dikilitas. 


\section{REFERENCES}

[1] Abedi, T., Mojiri, A. (2020): Cadmium uptake by wheat (Triticum aestivum L.): An overview. - Plants 9(4): 500.

[2] Ahmad, I. Z., Ahmad, A., Mabood, A., Tabassum, H. (2017): Effects of different metal stresses on the antioxidant defense systems of medicinal plants. - In: Khan, M., Iqbal, R., Khan, N. A. (eds.) Reactive oxygen species and antioxidant systems in plants: Role and regulation under abiotic stress. Springer, Singapore.

[3] Ahrens, U., Seemüller, E. (1992): Detection of DNA of plant pathogenic mycoplasmalike organisms by a polymerase chain reaction that amplifies a sequence of the 16S rRNA gene. - Phytopathology 82: 828-832.

[4] Al-Qurainy, F., Alameri, A. A., Khan, S. (2010): RAPD profile for the assessment of genotoxicity on a medicinal plant; Erucax sativa. - Journal of Medicinal Plants Research 4(7): 579-586.

[5] Al-Qurainy, F., Khan, S., Tarroum, M., Nadeem, M., Alansi, S., Alshameri, A. (2017): Biochemical and genetical responses of Phoenix dactylifera L. to cadmium stress. BioMed research international 9: 9504057.

[6] Andresen, E., Küpper, H. (2013): Cadmium toxicity in plants. - In: Sigel, A., Sigel, H., Sigel, R. K. O. (ed.) Cadmium: from toxicity to essentiality. Metal ions in life sciences. Springer, Netherlands.

[7] Arnon, D. L. (1949): A copper enzyme is isolated chloroplast polyphenol oxidase in Beta vulgaris. - Plant Physiol 24: 1-15.

[8] Bagheri, R., Bashir, H., Ahmad, J., Baig, A., Irfan, M. (2014): Qureshi Effects of Cadmium Stress on Plants. - Environmental Sustainability Concepts Principles Evidences Innovations 2014: 271-277.

[9] Basa, B., Lattanzio, G., Solti, Á. (2014): Changes induced by cadmium stress and iron deficiency in the composition and organization of thylakoid complexes in sugar beet (Beta vulgaris L.). - Environ. Exp. Bot. 101: 1-11.

[10] Bates, L. S., Waldren, R. P., Teare, I. D. (1973): Rapid determination of free proline for water-stress studies. - Plant and Soil 39: 205-207.

[11] Benavides, M. P., Gallego, S. M., Tomaro, M. L. (2005): Cadmium toxicity in plants. Brazilian Journal of Plant Physiology 17: 21-34.

[12] Beyersmann, D., Hartwig, A. (2008): Carcinogenic metal compounds: recent insight into molecular and cellular mechanisms. - Archives of Toxicology 82(8): 493-512.

[13] Cao, F., Chen, F., Sun, H., Zhang, G., Chen, Z. H., Wu, F. (2014): Genome-wide transcriptome and functional analysis of two contrasting genotypes reveals key genes for cadmium tolerance in barley. - BMC Genom 15(1): 611.

[14] Chaoui, A., Mazhoudi, S., Ghorbal, M. H., El Ferjani, E. (1997): Cadmium and zinc induction of lipid peroxidation and effects on antioxidant enzyme activities in bean (Phaseolus vulgaris L.). - Plant Science 127: 139-147.

[15] Chien, H. F., Wang, J. W., Lin, C. C., Kao, C. H. (2001): Cadmium toxicity of rice leaves is mediated through lipid peroxidation. - Plant Growth Regul. 33(3): 205-213.

[16] Cvikrova, M., Hrubcova, M., Vagner, M., Machackova, I., Eder, J. (1994): Phenolic acids and peroxidase activity in Alfalfa (Medicago sativa) embryogenic cultures after ethephon treatment. - Plant Physiological 91(2): 226-233.

[17] Dalcorso, G., Farinati, S., Maistri, S., Furini, A. (2008): How plants cope with cadmium: staking all on metabolism and gene expression. - Journal of Integrative Plant Biology 50: 1268-1280.

[18] Das, K., Roychoudhury, A. (2014): Reactive oxygen species (ROS) and response of antioxidants as ROS-scavengers during environmental stress in plants. - Frontiers in Environmental Science 2: 53. 
[19] Dias, M., Monteiro, C., Moutinho-Pereira, J., Correia, C., Gonçalves, B., Santos, C. (2013): Cadmium toxicity affects photosynthesis and plant growth at different levels. - Acta Physiol Plant 35: 1281-1289.

[20] Dikilitas, M. (2003): Effect of salinity \& its interactions with Verticillium albo-atrum on the disease development in tomato (Lycopersicon esculentum Mill.) and lucerne (Medicago sativa \& M. media) plants. - University of Wales, Swansea.

[21] Dikilitas, M., Kocyigit, A., Yigit, F. (2009): A molecular-based fast method to determine the extent of DNA damages in higher plants and fungi. - African Journal of Biotechnology 8(14): 3118-3127.

[22] Dikilitas, M., Kocyigit, A., Bilinc, H., Taskin, A., Karakas, S. (2015): Evaluation of genotoxicity of environmentally friendly pesticides on higher cells using the single cell gel electrophoresis (SCGE) assay. - Fresenius Environmental Bulletin 24: 39-47.

[23] Dutta, S., Mitra, M., Agarwal, P., Mahapatra, K., De, S., Sett, U., Roy, S. (2018): Oxidative and genotoxic damages in plants in response to heavy metal stress and maintenance of genome stability. - Plant Signal and Behavior 13(8): e1460048.

[24] Fagioni, M., D’Amici, G. M., Timperio, A. M., Zolla, L. (2009): Proteomic analysis of multiprotein complexes in the thylakoid membrane upon cadmium treatment. - Journal of Proteome Research 8(1): 310-326.

[25] Fodor, F. (2002): Physiological responses of vascular plants to heavy metals. - In: Prasad, M. N. V., Strzalka, K. (eds.) Physiology and Biochemistry of Metal Toxicity and Tolerance in Plants. Kluwer Academic, Dortrech, UK.

[26] Gallego, S. M., Benavídes, M. P., Tomaro, M. L. (1996): Effect of heavy metal ion excess on sunflower leaves: evidence for involvement of oxidative stress. - Plant Science 121: 151-159.

[27] Garg, N., Bhandari, P (2013): Cadmium toxicity in crop plants and its alleviation by arbuscular mycorrhizal (AM) fungi: An overview. - Plant Biosystems 148(4): 609-621.

[28] Gichner, T., Patková, Z., Száková, J., Demnerová, K. (2004): Cadmium induces DNA damage in tobacco roots, but no DNA damage, somatic mutations or homologous recombination in tobacco leaves. - Mutation Res. 559(1-2): 49-57.

[29] Gill, S. S., Tuteja, N. (2010): Reactive oxygen species and antioxidant machinery in abiotic stress tolerance in crop plants. - Plant Physiology and Biochemistry 48: 909-930.

[30] Gill, S. S., Hasanuzzaman, M., Nahar, K., Macovei, A., Tuteja, N. (2013): Importance of nitric oxide in cadmium stress tolerance in crop plants. - Plant Physiol. Biochem. 63: 254261.

[31] Guo, H., Hong, C., Chen, X., Xu, Y., Liu, Y., Jiang, D., Zheng, B. (2016): Different growth and physiological responses to cadmium of the three Miscanthus species. - PLoS ONE 11(4): e0153475.

[32] Islam, M. M., Hoque, M. A., Okuma, E., Jannat, R., Banu, M. N., Jahan, M. S., Nakamura, Y., Murata, Y. (2009): Proline and Glycinebetaine Confer Cadmium Tolerance on Tobacco Bright Yellow-2 Cells by Increasing Ascorbate-Glutathione Cycle Enzyme Activities. Bioscience Biotechnology and Biochemistry 73(10): 2320-2323.

[33] Jaskulak, M., Rorat, A., Grobelak, A., Kacprzak, M. (2018): Antioxidative enzymes and expression of rbcL gene as tools to monitor heavy metal-related stress in plants. - Journal of Environmental Management 218: 71-78.

[34] Jasoni, R. L., Cothren, J. T., Morgan, P. W., Sohan, D. E. (2002): Circadian ethylene production in cotton. - Plant Growth Regulation 36(2): 31-37.

[35] Karakas, S., Dikilitas, M., Tipırdamaz, R. (2019): Biochemical and molecular tolerance of Carpobrotus acinaciformis $\mathrm{L}$. halophyte plants exposed to high level of $\mathrm{NaCl}$ stress. Harran Journal of Agricultural and Food Science 23(1): 99-107.

[36] Karuppanapandian, T., Kim, W. (2013): Cobalt-induced oxidative stress causes growth inhibition associated with enhanced lipid peroxidation and activates antioxidant responses in Indian mustard (Brassica juncea L.) leaves. - Acta Physiologiae Plantarum 35(8): 24292443. 
[37] Kassaye, Y. A., Salbu, B., Skipperud, L., Einset, J. (2013): High tolerance of aluminum in the grass species Cynodon aethiopicus. - Acta Physiol Plant 35: 1749-1761.

[38] Kaur, G., Asthir, B. (2015): Proline: a key player in plant abiotic stress tolerance. - Biologia Plantarum 59: 609.

[39] Konca, K., Lankoff, A., Banasik, A., Lisowska, H., Kuszewski, T., Gozdz, S., Koza, Z., Wojcik, A. (2003): A cross-platform public domain PC image-analysis program for the comet assay. - Mutation Research 534: 15-20.

[40] López-Millán, A. F., Sagardoy, R., Solanas, M., Abadía, A., Abadía, J. (2009): Cadmium toxicity in tomato (Lycopersicon esculentum) plants grown in hydroponics. - Environ Exp Bot. 65: 376-385.

[41] Lozano-Rodriguez, E., Hernàndez, L. E., Bonay, P., Carpena-Ruiz, R. O. (1997): Distribution of cadmium in shoot and root tissues of maize and pea plants: physiological distribution. - Journal of Experimental Botany 48: 123-128.

[42] Milosevic, N., Slusarenko, A. J. (1996): Active Oxygen Metabolism and Lignifications in The Hypersensitive Response in Bean. - Physiological and Molecular Plant Pathology 49: 143-158.

[43] Monteiro, M., Santos, C., Mann, R. M., Soares, A. M. V. M., Lopes, T. (2007): Evaluation of cadmium genotoxicity in Lactuca sativa L. using nuclear microsatellites. Environmental and Experimental Botany 60(3): 421-427.

[44] Nazar, R., Iqbal, N., Masood, A., Khan, R., Khan, N. (2012): Cadmium Toxicity in Plants and Role of Mineral Nutrients in Its Alleviation. - American Journal of Plant Sciences 3: 1476-1489.

[45] Noor, W., Umar, S., Mir, M. Y., Shah, D., Majeed, G., Hafeez, S., Yaqoob, S., Gulzar, A., Kamili, A. N. (2018): Effect of Cadmium on Growth, Photosynthesis and Nitrogen Metabolism of Crop Plants. - Journal of Research and Development 18: 100-106.

[46] Ovecka, M., Takac, T. (2014): Managing heavy metal toxicity stress in plants: Biological and biotechnological tools. - Biotechnology Advances 32: 73-86.

[47] Paunov, M., Koleva, L., Vassilev, A., Vangronsveld, J., Goltsev, V. (2018): Effects of different metals on photosynthesis: cadmium and zinc affect chlorophyll fluorescence in durum wheat. - International Journal of Molecular Sciences 19(3): 787.

[48] Romero-Puertas, M. C., Rodríguez-Serrano, M., Corpas, F. J., Gomez, M. D., Del Rio, L. A., Sandalio, L. M. (2004): Cadmium-induced subcellular accumulation of $\mathrm{O}_{2}{ }^{-}$and $\mathrm{H}_{2} \mathrm{O}_{2}$ in pea leaves. - Plant Cell Environ 27(9): 1122-1134.

[49] Sairam, R. K., Sexena, D. (2000): Oxidative stress and antioxidants in wheat genotypes: possible mechanism of water stress tolerance. - Journal of Agronomy and Crop Science 184: 55-61.

[50] Sandalio, L. M., Dalurzo, H. C., Gómez, M., Romero-Puertas, M. C., Del Rio, L. A. (2001): Cadmium-induced changes in the growth and oxidative metabolism of pea plants. - Journal of Experimental Botany 52(364): 2115-2126.

[51] Shanmugaraj, B. M., Malla, A., Ramalingam, S. (2019): Cadmium Toxicity and Tolerance in Plants. From Physiology to Remediation. - In: Hasanuzzaman, M., Prasad, M. N. V., Fujita, M. (eds.) Cadmium Stress and Toxicity in Plants: An Overview. Elsevier.

[52] Smeets, K., Ruytinx, J., Semane, B., Van Belleghem, F., Remans, T., Van Sanden, S., Vangronsveld, J., Cuypers, A. (2008): Cadmium-induced transcriptional and enzymatic alterations related to oxidative stress. - Environmental and Experimental Botany 63: 1-8.

[53] Solti, Á., Sárvári, É., Tóth, B., Basa, B., Lévai, L., Fodor, F. (2011): Cd affects the translocation of some metals either Fe-like or Ca-like way in poplar. - Plant Physiol Biochem. 49: 494-498.

[54] Surapu, V., Ediga, A., Meriga, B. (2014): Salicylic Acid Alleviates Aluminum Toxicity in Tomato Seedlings (Lycopersicum esculentum Mill.) through Activation of Antioxidant Defense System and Proline Biosynthesis. - Advances in Bioscience and Biotechnology 5: 777-789. 
[55] Tamás, M. J., Sharma, S. K., Ibstedt, S., Jacobson, T., Christen, P. (2014): Heavy metals and metalloids as a cause for protein misfolding and aggregation. - Biomolecules 4(1): 252-267.

[56] Tran, T. A., Popova, L. P. (2013): Functions and toxicity of cadmium in plants: recent advances and future prospects. - Turkish Journal of Botany 37: 1-13.

[57] Velikova, V., Yordanov, I., Edreva, A. (2000): Oxidative Stress and Some Antioxidant Systems in Acid RainTreated Bean Plants: Protective Role of Exogenous Polyamines. Plant Science 151: 59-66.

[58] Walinga, I., Van Vark, W., Houba, V. J. G., Van der Lee, J. J. (1989): Soil and Plant Analysis, Part 7: Plant Analysis Procedures. - Wageningen Agricultural University, 263p.

[59] Xie, Y., Wang, J., Zheng, L., Wang, Y., Luo, L., Ma, M., Zhang, C., Han, Y., Beeckman, Y., Xu, G., Cai, Q., Xuan, W. (2019): Cadmium stress suppresses lateral root formation by interfering with the root clock. - Plant Cell Environ 42: 3182-3196.

[60] Yadav, S. K. (2010): Heavy metals toxicity in plants: an overview on the role of glutathione and phytochelatins in heavy metal stress tolerance of plants. - South African Journal of Botany 76(2): 167-179.

[61] Yilmaz, D. D., Parlak, K. U. (2011): Changes in proline accumulation and antioxidative enzyme activities in Groenlandia densa under cadmium stress. - Ecological Indicators 11: 417-423.

[62] Zhang, S., Zhang, H., Qin, R., Jiang, W., Liu, D. (2009): Cadmium induction of lipid peroxidation and effects on root tip cells and antioxidant enzyme activities in Vicia faba $\mathrm{L}$. - Ecotoxicology 18(7): 814-823.

[63] Zhang, C., Sale, P. W. G., Doronila, A. I., Clark, G. J., Livesay, C., Tang, C. (2014): Australian native plant species Carpobrotus rossii (Haw.) Schwantes shows the potential of cadmium phytoremediation. - Environ Sci Pollut Res. 21: 9843-9851.

[64] Zhang, C., Sale, P. W. G., Clark, G. J., Doronila, A. I., Kolev, S. D., Tang, C. (2015): Succulent species differ substantially in their tolerance and phytoextraction potential when grown in the combinations of $\mathrm{Cd}, \mathrm{Cr}, \mathrm{Cu}, \mathrm{Mn}, \mathrm{Ni}, \mathrm{Pb}$ and $\mathrm{Zn}$. - Environ Sci Pollut Res. 22: 18824-18838.

[65] Zhang, C., Sale, P. W. G., Tang, C. (2016): Cadmium uptake by Carpobrotus rossii (Haw.) Schwantes under different saline conditions. - Environ Sci Pollut Res. 23: 13480-13488.

[66] Zhang, H., Xu, Z., Guo, K., Huo, Y., He, G., Sun, H., Guan, Y., Xu, N., Yang, W., Sun, G. (2020): Toxic effects of heavy metal $\mathrm{Cd}$ and $\mathrm{Zn}$ on chlorophyll, carotenoid metabolism and photosynthetic function in tobacco leaves revealed by physiological and proteomics analysis. - Ecotoxicology and Environmental Safety 202: 110856. DOI: 10.1016/j.ecoenv.2020.110856.

[67] Zouari, M., Ben Ahmed, C., Elloumi, N., Bellassoued, K., Delmail, D., Labrousse, P., Ben Abdallah, F., Ben Rouina, B. (2016): Impact of proline application on cadmium accumulation, mineral nutrition and enzymatic antioxidant defense system of Olea europaea L. cv Chemlali exposed to cadmium stress. - Ecotoxicol Environ Saf. 128: 195205. 